\title{
Establishment of Native Wildflower Plantings by Seed ${ }^{1}$
}

\author{
Jeffrey G. Norcini and James H. Aldrich ${ }^{2}$
}

\section{Introduction}

Interest in planting native wildflowers along Florida's roadsides and in meadows has grown steadily over the past $30-40$ years, and especially so more recently. The most common method to establish these plantings is by direct seeding. This publication describes direct seeding methods you can use to establish medium to large size native wildflower plantings, such as those on roadsides, meadows, commercial properties, and right-of-ways."

Obtaining a sustainable population of native wildflowers from seed requires that appropriate practices be used to establish the planting. The recomendations in this publication reflect a few general guidelines:

- select species most suitable to the site

- promote best possible germination and recruitment

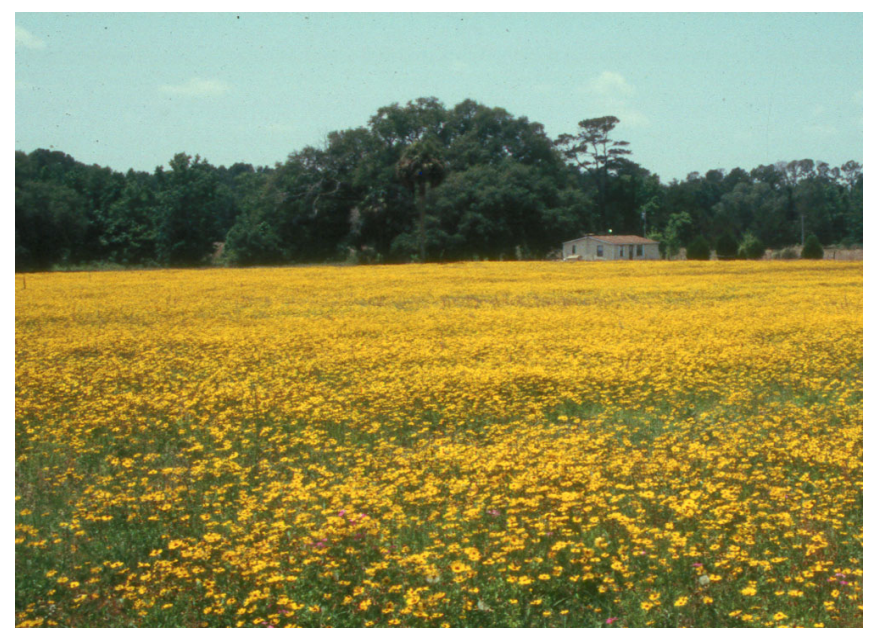

Figure 1. Large meadow of goldenmane tickseed. Credits: Gary Henry

- provide weed control

\section{Site Considerations}

Select and prepare the planting site with the goal of minimizing weed interference with germination of wildflower seed and their subsequent growth. It is also important to identify weeds in and around the

1. This document is ENH 968, one of a series of the Environmental Horticulture Department, Florida Cooperative Extension Service, Institute of Food and Agricultural Sciences, University of Florida. Original publication date April 2004. Visit the EDIS Web Site at http://edis.ifas.ufl.edu. For a thorough review of this subject, see "Factors and Benefits in the Establishment of Modest-Sized Wildflower Plantings: A Review" (1).

2. Jeffrey G. Norcini, Associate Professor, native wildflower specialist, and James H. Aldrich, Senior Biological Scientist, North Florida Research \& Education Center, Quincy, FL 32351.

The use of trade names in this publication is solely for the purpose of providing specific information. UF/IFAS does not guarantee or warranty the products named, and references to them in this publication do not signify our approval to the exclusion of other products of suitable composition. All chemicals should be used in accordance with directions on the manufacturer's label. Use pesticides safely. Read and follow directions on the manufacturer's label. *Note: The underlying principles mentioned in this publication would be useful to those involved in restoration or reclamation, those trying to preserve a naturally occurring native wildflower population, and those establishing small wildflower plantings in residential sites, but methods applicable to those situations are specialized and are not addressed in this publication.

The Institute of Food and Agricultural Sciences (IFAS) is an Equal Employment Opportunity - Affirmative Action Employer authorized to provide research, educational information and other services only to individuals and institutions that function without regard to race, creed, color, religion, age, disability, sex, sexual orientation, marital status, national origin, political opinions or affiliations. For information on obtaining other extension publications, contact your county Cooperative Extension Service office. Florida Cooperative Extension Service/Institute of Food and Agricultural Sciences / University of Florida / Larry R. Arrington, Interim Dean 
site prior to planting so that you know what weed problems might be encountered and what practices can be used to control them.

\section{Site Selection}

There are two approaches to selecting a site: (1) locate a site that favors establishment of a sustainable planting, or (2) choose a species or a few species first, and then find the site that's most suitable. Regardless of the approach, site conditions need to favor wildflower seed germination and sustainability of the planting.

\section{Choosing A Site For Sustainable Plantings}

- Choose a site with a sparse weed population. At sites where weed growth is dense, there is probably a substantial weed seed bank in the top 2-3 inches of soil. Inhibiting germination and growth of weeds at sites that strongly support their presence could be costly or futile when trying to establish a wildflower planting.

- Steer clear of sites with a considerable number of yellow or purple nutsedge (Cyperus esculentus and Cyperus rotundus, respectively). They are difficult to eliminate, seem to spread rapidly, and are extremely competitive.

- If the site is in turf, choose an area where the turf cover is thin or moderate (Figure 2). Avoid areas of thick turf. While grass herbicides can help control grasses, site conditions that support thick turf probably would favor weed growth as well.

- Avoid sites with extremely compacted soil. These sites might seem ideal because of sparse weed growth but preparing the site so that it is suitable for a wildflower planting could be costly.

- Sites where the topsoil has been scraped off, like roadside construction areas, are suitable for wildflowers if the soil is not too compacted. Weed seed are mainly in the top 2-3 inches of soil, and at least that much is usually removed during road construction or renovation.

- Many of Florida's common native wildflower species prefer soils of low to poor fertility, and under those conditions they usually can compete well with weeds.

-Wildflowers tend to be outcompeted by weeds under traditional garden type conditions-loose, well-drained, nutrient-rich soils that rarely dry out.

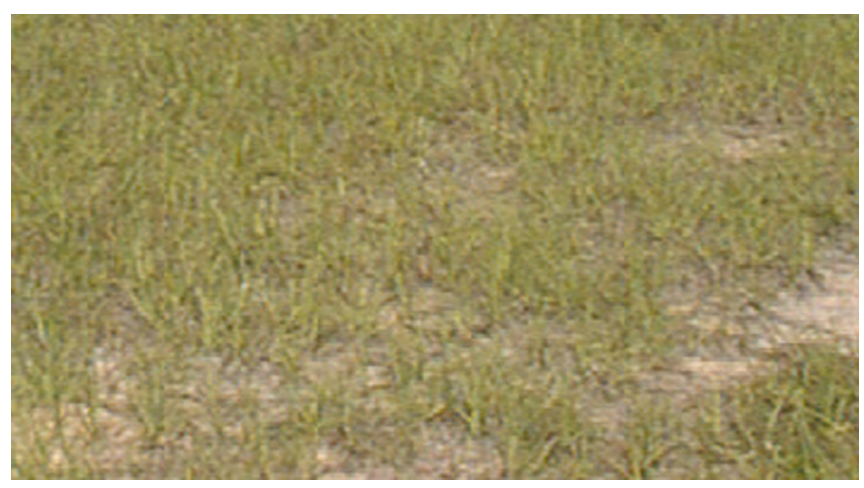

Figure 2. Areas with sparse bahiagrass, which frequently occur in sandy soil, are ideal for wildflower plantings. Credits: Jeff Norcini

\section{Select Appropriate Species}

Selecting species that are native to Florida and appropriate for the site is a crucial aspect of establishing a planting with long-term sustainability. Such species have the best chance of thriving and reproducing if managed properly. Choose species whose natural habitat most closely matches the planting site. Soil type and moisture, sun or shade preference, cold hardiness, heat tolerance, and salt tolerance (for coastal sites) need to be considered. Consult the references in Table 1 for assistance.

The list of native wildflowers suitable for the site can be narrowed by preferences for growth habit, flowering season, flower color, and life cycle (annual, biennial, or perennial) in your region of Florida. Life cycle of plants can vary from northern to southern Florida and vice versa. A perennial in southern Florida might be an annual in northern Florida, and a perennial in northern Florida might be an annual in southern Florida due to prolonged warm temperatures and high humidity in southern Florida. Use references in Table 1, but also confer with local native plant experts. They frequently can tell you which wildflowers perform best in the local area. 
Locate a seed supplier and find out the origin of the seed. Whenever possible, purchase seed that is derived from native Florida populations since wildflowers in natural stands probably are better adapted to Florida's environment than seed sold by out-of-state suppliers. In studies conducted under Florida conditions, seed origin affected growth, flowering, and/or survival of native wildflowers $(5,8$, 9, 10). For example, lanceleaf tickseed (Coreopsis lanceolata) derived from native Florida populations flowered the spring after seed were sown in late fall in a northern Florida field trial, while the variety typically purchased in seed packets at garden outlets flowered poorly in these same trials the first spring after sowing (8). In addition, black-eyed Susan (Rudbeckia hirta) derived from Florida populations consistently outlived its counterpart from an out-of-state commercial seed supplier $(5,10)$. Seed of wildflowers adapted to Florida's environment have recently become available with the advent of a small but expanding native wildflower seed industry in Florida. For more information, go to http://floridawildflowers.com.

If the planting will be a mix or mosaic (small plots of monocultures adjacent to each other), there are several issues to consider. Seed mixes, and mosaics to some degree, give a more natural look to the planting, but the appearance of the planting probably will differ each year. Consult the resources listed in Table 1 to determine which species grow best together. When deciding on proportions of each species, consider growth habit, season of flower, flower color, life cycle, and aggressiveness. Blanketflower (Gaillardia pulchella), for example, is very aggressive and should comprise a relatively low percentage of the mix compared to less aggressive species. True perennials should also be a low percentage of the mix.

Finally, try to determine which weeds could pose a problem during establishment. Being aware of potential weed problems and practices required to control those weeds could influence the choice of wildflower species.

\section{Site Preparation}

The goal of site preparation is to facilitate wildflower seed germination and subsequent growth while minimizing interference by weeds or turf grasses. In most cases the no till/minumim till method can accomplish this. An alternative method can be used for annual wildflower species when the site is in bahiagrass.

No Till/Minimum Till. About 4 weeks before sowing seed, kill existing vegetation with a nonselective, translocated herbicide that contains as the only active ingredient either glyphosate (for example, Roundup ${ }^{\circledR}$ ) or glufosinate $\left(\right.$ Finale $^{\circledR}$ ). More than one application probably will be needed to eradicate the weeds; the second application should be about 2 weeks after the first application. About 2 weeks after the second application, mow the dead vegetation close to the soil. Most clippings need to be removed because they could prevent wildflower seed from reaching the soil. Clippings also could heat up as they decompose (essentially "composting"), and the moist heat could cause wildflower seed to deteriorate. It may be possible to burn off vegetation if the appropriate local and/or state agency permits. Check with your county agent to find out which local and/or state agency needs to be contacted to receive a burning permit.

If the soil is not loose and seed will not be sown with a seed drill, then lightly scarify the site with a disk or harrow so that the soil surface is barely scratched, keeping in mind that most weed seed are in the top 2-3 inches. Disking or harrowing at least once in a perpendicular direction will increase the amount of soil surface that is scarified. Lightly scratching the soil facilitates good seed-to-soil contact while minimizing soil disturbance that creates weed problems.

If the soil is loose, like a sandy soil, then it does not need to be scarified. However, the seed bed needs to be firm so that the sown seed remains in the top $1 / 4-1 / 8$ inch after planting since seeds of many wildflower species are very small and require light to germinate. Use a turf roller, cultipacker, or some other implement to firm the soil. 
Sites in Bahiagrass. Some spring annual wildflower species like goldenmane tickseed (Coreopsis basalis) and annual phlox (Phlox drummondii) coexist well with bahiagrass when there are several inches between clumps of bahiagrass (Figure 2) and the soil is loose (typically sandy) and well-drained. Most growth and flowering of these species occurs when bahiagrass is slow-growing or dormant. No site preparation is needed other than mowing the bahiagrass in the fall prior to seeding.

\section{Planting}

\section{Time of Year}

It is best to sow native wildflower seed in late summer through mid fall since rainfall and soil temperature should be adequate for seed to germinate by the end of fall. Seed planted in late fall or winter may not germinate for many weeks because of colder soil and/or less rain. If you seed later in the year, pay particular attention to weed control as there are many cool-season weeds that could emerge before the wildflowers germinate. Seed sown earlier in the season usually germinate faster, which may help give wildflower seedlings a competitive edge over emerging weed growth.

\section{Seeding Rates}

Information about seeding rates for Florida-adapted native wildflower seed is extremely limited. Until more information is known about seeding rates for Florida-adapted seed, use the rates listed in Table 2; for unlisted species, use $10 \mathrm{lb}$ per acre as a starting point but $20 \mathrm{lb}$ per acre for legumes. For non-Florida seed, rates typically are $2-10 \mathrm{lb}$ of bulk seed per acre depending on species; follow supplier recommendations for seeding rate. Regardless of seed origin, if Plateau ${ }^{\circledR}$ herbicide (see Weed Control; Table 3, Table 4) is to be applied prior to emergence of wildflower seedlings, increase the seeding rate by $10-20 \%$ to overcome potential stand thinning by Plateau ${ }^{\circledR}$. One exception is annual phlox. Studies at the NFREC and those of others have shown that annual phlox tends to be very tolerant when Plateau ${ }^{\circledR}$ is applied prior to emergence.

\section{Sowing Seed}

Many native wildflower species are small-seeded and require light for germination. Therefore, sow seed about 1/8 inch deep but no more than $1 / 4$ inch. At large sites, wildflower seed are frequently sown with a seed drill. Drill seeding virtually assures shallow planting depth and good soil-to-seed contact. It is used in combination with the no till/minimum till site preparation method described before. An advantage of drill seeding is that the soil does not need to be scratched prior to seeding. This reduces site preparation costs and weed pressure. Sites that are drill seeded will have an "unnatural" linear or row appearance but this can be overcome by drilling half the seed at right angles to each other (4).

Hydroseeding, also called hydromulching, is another method for seeding large sites. It is especially useful for seeding slopes and other areas that are not suitable for drill seeding. A slurry of seed and fiber is mixed in a tank and applied with a hose. Since the seed/fiber slurry is applied to the soil surface, nonsandy soils should be lightly scratched for good soil-to-seed contact. Alternatively, a mixture of seed and water can be applied, followed by a thin layer of mulch. Do not use hay mulch as it could contain weed seed.

If a seed drill or hydroseeder is not available, or if the site is inaccessible to machinery or on a steep slope, a manually operated rotary spreader can be used. Seed are mixed with with 1 part seed to 4 parts slightly moistened sand or vermiculite. Hand seeding will take about 3/4 to 1 hour per acre. After seed are sown, use a drag bar, turf roller, or some other process to improve seed-to-soil contact.

The methods described above are for sowing essentially pure seed. An alternative method-commonly known as flower hay, seed hay, or hay strewing - makes use of impure seed. This method is utilized in restoration projects but could prove especially useful to those establishing native wildflower plantings on roadsides or right-of-ways. About 2-3 weeks after peak bloom, and before seed drop, hay from natural wildflower stands can be harvested and then redistributed in a thin layer on the area to be planted. Harvest the seed hay from 
different portions of the stand, and do not harvest more than $30-40 \%$ of the stand. Spread the seed hay the day it is harvested. The seed hay is comprised of a lot of plant material that will heat up within a day or two after harvest if left in a pile-the moist heat will kill or damage seed. For details about this method, see Aldrich (1).

\section{Establishment and Maintenance}

\section{Weed Control}

Weed competition is one of the primary reasons that wildflower plantings deteriorate a year or two after establishment or fail to become established at all. As mentioned before, it is important to identify weeds in and around the site prior to planting. These probably will be the weeds that you will have to be prepared to deal with.

Once seed are sown, consider applying Plateau ${ }^{\circledR}$ (Table 3, Table 4) a day or two later. It is the only herbicide labelled for use on noncrop sites that have been freshly seeded with native wildflowers.

(NOTE: Plateau ${ }^{\circledR}$ is available only to local, state, and federal government agencies.) Many native wildflower species are moderately to highly tolerant of Plateau ${ }^{\circledR}$. Native wildflowers, including Florida-adapted ones, are most tolerant when Plateau $^{\circledR}$ is applied prior to their emergence. While the herbicide may cause some stand thinning and slight injury, the weed control benefits outweigh the minor phytotoxic effects. Stand thinning can be overcome by seeding at 10-20\% greater than recommended rates. Injury symptoms, which are usually transient, include stunting, chlorosis, and/or reddish to purplish foliage. Plateau ${ }^{\circledR}$ also can be tank-mixed with Pendulum ${ }^{\circledR}$ WDG (Table 4) to prolong preemergent control of weeds and/or to expand the spectrum of weed species to be controlled. Check the Plateau ${ }^{\circledR}$ label for tank mix recommendations and wildflower species that are tolerant of this combination.

Since some weeds inevitably will emerge, their growth needs to be controlled to minimize their interference with growth of wildflower seedlings. While wildflower seedlings are small, mow sites as needed to minimize weed growth and flowering.
When wildflower seedling height precludes mowing, use postemergent herbicides to kill existing weeds if necessary. Grasses are usually the easiest weeds to control. Use postemergence application(s) of graminocides, herbicides designed only to kill grasses (Table 5, Table 6). Other weeds can be controlled with applications(s) of a nonselective herbicide that contains glyphosate (for example, Roundup $^{\circledR}$ ) or glufosinate (Finale ${ }^{\circledR}$ ) as the only active ingredient. Apply these herbicides either as directed spray with a shielded nozzle, or with a rope or wick applicator to weeds that rise above the wildflower canopy.

Plateau $^{\circledR}$ is an alternative for broad spectrum postemergence weed control. Since many wildflowers tend to be more sensitive to Plateau ${ }^{\circledR}$ when it is applied to established plants, base a decision about whether to apply Plateau ${ }^{\circledR}$ on the severity of the weed competition, the level of tolerable injury, and the long-term benefits. Some injury is likely to occur but it has been clearly shown that Plateau ${ }^{\circledR}$ can improve the overall quality of native wildflower and grass stands in the long term $(2,3,6)$. In our studies, minor stunting and chlorosis were transient and plants eventually grew normally (7). Delayed flowering was also observed. Do not apply Plateau ${ }^{\circledR}$ on established blanketflower as it is very sensitive.

Once wildflower seedlings are a few inches tall, preemergent herbicides can be used, if necessary, to prevent additional weed emergence. Tables 3 and 4 list preemergent herbicides labelled for use on established wildflowers.

Some pre- and postemergent herbicides can be used on wildflower species other than those genera or species listed on the label as being tolerant (Table 3, Table 5). These herbicides will have specific wording on the label that clearly states this. Chemical companies have allowed such use because they recognize that they cannot possibly evaluate tolerance of every ornamental species, cultivar, etc. to a specific herbicide. However, first evaluate tolerance on a small portion of the nonlabelled species before applying the herbicide to the entire planting. Secondly, the user accepts all liability. Carefully read and follow all label directions when using any herbicide under these conditions. 
A Note About Herbicide Use. Efficacy and phytotoxicity of herbicides can vary depending on weather, soil, and seed source. Since information about tolerance of Florida-adapted native wildflowers under field conditions is very limited, consider evaluating wildflower tolerance to a specific herbicide on a small portion of the planting before applying the herbicide to the entire planting. Injury to plants such as yellowing, reddening, and brown spots could be evident in as little as a few days after application. To be sure that injury was caused by the herbicide, compare the apparently injured plants to several nontreated plants in different parts of the planting. Bear in mind that injury symptoms might be slow to develop. In cold weather, injury might not be apparent for several weeks. Stunting or inhibition of flowering also might take several weeks before it is evident.

\section{Mowing}

Mowing during the first year of establishing a wildflower planting from seed primarily is used for weed control. As mentioned before, plots can be mowed while seedlings remain below mower height. Frequency of mowing over the top of wildflower seedlings will depend on weed growth. If recommendations for site selection and preparation were followed, there should be minimal need for mowing to control weed growth. Herbicide use will reduce or eliminate the need for mowing.

It is important to know the life cycle and blooming season of specifc wildflower species in order to utilize a mowing regime that will facilitiate a sustainable planting. Keep in mind that life cycle and blooming season could vary substantially depending on the region of Florida. An annual in northern Florida might be a perennial in southern Florida and vice versa. Consult the references in Table 1 as well as local experts.

Additional mowing during the first year should not be done until after flowering. Wait at least 3 weeks after peak bloom before mowing, but the longer the time between peak flowering and mowing the greater the seed set. In rural areas, consider keeping mowing regimes to a minimum, perhaps as few as two to three cycles per year. Often in areas where mowing frequency has been reduced, native wildflowers and grasses appear that were not known to previously exist at the site (Figure 3).

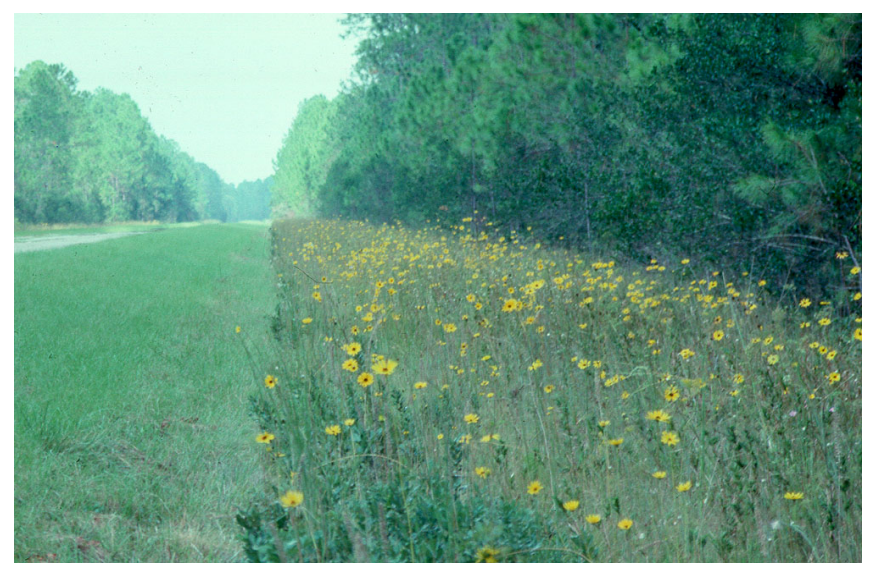

Figure 3. Because a portion of the right-of-way was not mowed during the summer, this naturally-occurring Florida native tickseed (Coreopsis linifolia) flowered in the fall. Credits: Gary Henry

Native species that emerge in the areas where mowing frequency is reduced not only enhance diversity but enhance aesthetics and extend the length of time the planting is showy. For example, blazing stars (Liatris spp.), deer tongues (Carphephorus spp.), sunflowers (Helianthus spp.), goldenasters (Pityopsis spp.), and some tickseeds (Coreopsis spp.) (Figure 3) commonly occur in most parts of Florida. These attractive natives will flower in late summer or mid fall if summer mowing is suppressed and the plants are allowed to develop.

\section{Irrigation}

Applying enough supplemental irrigation to benefit germination in large plantings probably is not practical. However, if irrigation is availabIe, consider applying 1/4 inch per day for 2 weeks after sowing seed. Using this regime under northern Florida conditions, fair to good germination was observed for lanceleaf tickseed, goldenmane tickseed, blanketflower, and annual phlox planted in early November.

\section{Fertilization}

Generally, supplemental fertilization is not recommended. Since plantings will be mowed, nutrients will be recycled as the clippings decompose. Consider, too, that many of Florida's native 
wildflower species are adapted to soils with low fertility and perform well under those conditions. Excess fertilization will promote vegetative growth over flowering, might make wildflowers more susceptible to insect and disease pests, and will promote weed growth.

\section{Stand Appearance and Longevity}

If the site has been planted as a mosaic, there will be unavoidable intermingling of the species. But that is one of the appealing aspects of wildflower plantings. And no matter if the planting is a mix or mosiac, the plantings will look different each year as different species may predominate because of weather, maintenance practices, and the inherent nature of individual species. If Florida-adapted native wildflowers were used, the stand should be sustainable for many years provided that the site is appropriate for the species and suitable weed management and mowing practices are utilized.

\section{References}

1. Aldrich, J.H. 2002. Factors and benefits in the establishment of modest-sized wildflower plantings: a review. Native Plants Journal 3:65-73, 77-86.

2. Beran, D.D., R.E. Gaussoin, and R.A. Masters. 1999. Native wildflower establishment with imidazolinone herbicides. HortScience 34:283-286.

3. Beran, D.B., R.A. Masters, and R.E. Gaussoin. 1999. Grassland legume establishment with imazethapyr and imazapic. Agron. J. 91:592-596.

4. Lickorish, S., G. Luscombe, and R. Scott. 1997. Wildflowers work: technical guide to creating and maintaining wildflower landscapes. Liverpool, United Kingdom: Landlife, 45 pp.

5. Marois, J.J. and J.G. Norcini. 2003. Survival of black-eyed Susan (Rudbeckia hirta L.) from different regional seed sources under low and high input systems. HortTech. 13(1):161-165.

6. Masters, R.A., S.J. Nissen, R.E. Gaussoin, D.D. Beran, and R.N. Stougaard. 1996. Imidazolinone herbicides improve restoration of Great Plains grasslands. Weed Tech. 10:392-403.
7. Norcini, J.G. and J.H. Aldrich. 2000. Effects of Plateau on native wildflower plantings. Proc. Southern Nursery Assoc. Res. Conf. 45:362-365.

8. Norcini, J.G, J.H. Aldrich, L.A. Halsey, and J.G. Lilly. 1998. Seed source affects performance of six wildflower species. Proc. Fla. State Hort. Soc. 111:4-9.

9. Norcini, J.G., J.H. Aldrich, and F.G. Martin. 2001. Seed source affects growth and flowering of Coreopsis lanceolata and Salvia lyrata. J. Environ. Hort. 19:212-215.

10. Norcini, J.G., M. Thetford, K.A.

Klock-Moore, M.L. Bell, B.K. Harbaugh, and J.H. Aldrich. 2001. Growth, flowering, and survival, of black-eyed Susan from different regional seed sources. HortTech. 11:26-30. 
Table 1. Resources for wildflower information—plant characteristics, flowering season, native habitat, and regions of Florida where the species grow.

\section{Books* $^{*}$}

Bell, C.R. and B.J. Taylor. 1982. Florida Wild Flowers and Roadside Plants. Laurel Hill Press, Chapel Hill, NC. (ISBN 0-9608688-0-1)

Clewell, A.F. 1985. Guide to the Plants of the Florida Panhandle. University Press of Florida, Gainesville, FL. (ISBN 0-8130-0779-8)

Hammer, R.L. 2002. Everglades Wildflowers. The Globe Pequot Press, Guilford, CT. (ISBN 0-7627-1089-6)

Schmelz G.W. and G. Stacell. 2001. A Guide to Common Native Wildflowers of Collier County, Florida. (no printing company listed) (ISBN 0-9708582-0-5)

Schuyler, A.A. 1982. Wildflowers: South Florida Natives. FACTS, Boca Raton, FL. (ISBN 0-910991-00-6)

Taylor, W.K. 1992. The Guide to Florida Wildflowers. Taylor Publishing Company, Dallas, TX. (ISBN 0-87833-747-4)

Taylor, W.K. 1998. Florida Wildflowers in Their Natural Communities. University Press of Florida, Gainesville, FL. (ISBN 0-8130-1616-9)

Wunderlin, R.P. 1998. Guide to the Vascular Plants of Florida. University Press of Florida, Gainesville, FL. (ISBN 0-8130-1556-1)

* ISBN numbers are included to make it easier to locate these books in a library or via the internet.

\section{Internet}

Atlas of Florida Vascular Plants (http://plantatlas.usf.edu)

Wunderlin, R. P., and B. F. Hansen. 2003. Atlas of Florida Vascular Plants (http://www.plantatlas.usf.edu/). [S. M.

Landry and K. N. Campbell (application development), Florida Center for Community Design and Research.] Institute for Systematic Botany, University of South Florida, Tampa.

Florida Native Plant Society (http://www.fnps.org)

Florida's Native Plants (http://www.nsis.org/garden/)

Florida Wildflowers (http://www.flwildflowers.com/)

Table 2. Bulk seeding rates for Florida-adapted native wildflowers.

\begin{tabular}{||l|l|r||}
\hline \hline Common name(s) & Scientific name & Rate (lb/A) \\
\hline black-eyed Susan & Rudbeckia hirta & 2 to 10 \\
\hline blanketflower; firewheel; indian blanket & Gaillardia pulchella & 10 \\
\hline Drummond phlox; annual phlox & Phlox drummondii & 10 \\
\hline goldenmane tickseed; dye flower & Coreopsis basalis & 10 \\
\hline lanceleaf tickseed & Coreopsis lanceolata & 10 to 15 \\
\hline Leavenworth's tickseed & Coreopsis leavenworthii & 6 to 10 \\
\hline standing cypress; Spanish larkspur & Ipomopsis rubra & \\
\hline \hline
\end{tabular}


Table 3. Preemergent herbicide products and specific formulations that can be used on wildflower species other than those listed on the label as being tolerant. Details about labelled formulations are in parentheses if all formulation information is not part of the product name.

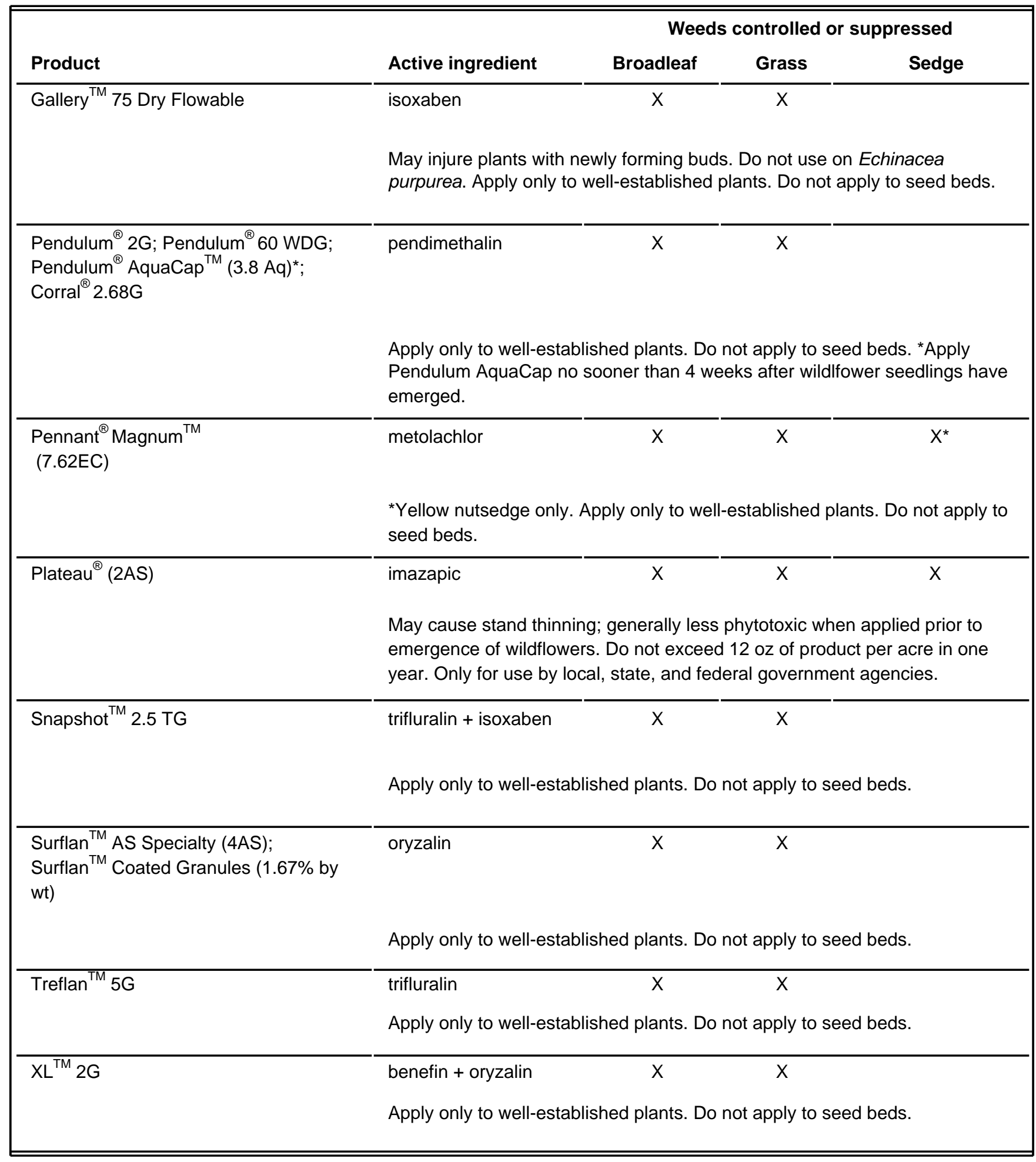


Table 4. Preemergent herbicide products and specific formulations labelled for use only on specific genera or species of wildflowers. Details about labelled formulations are in parentheses if all formulation information is not part of the product name. Check the label for the list of wildflower species on which these products can be used.

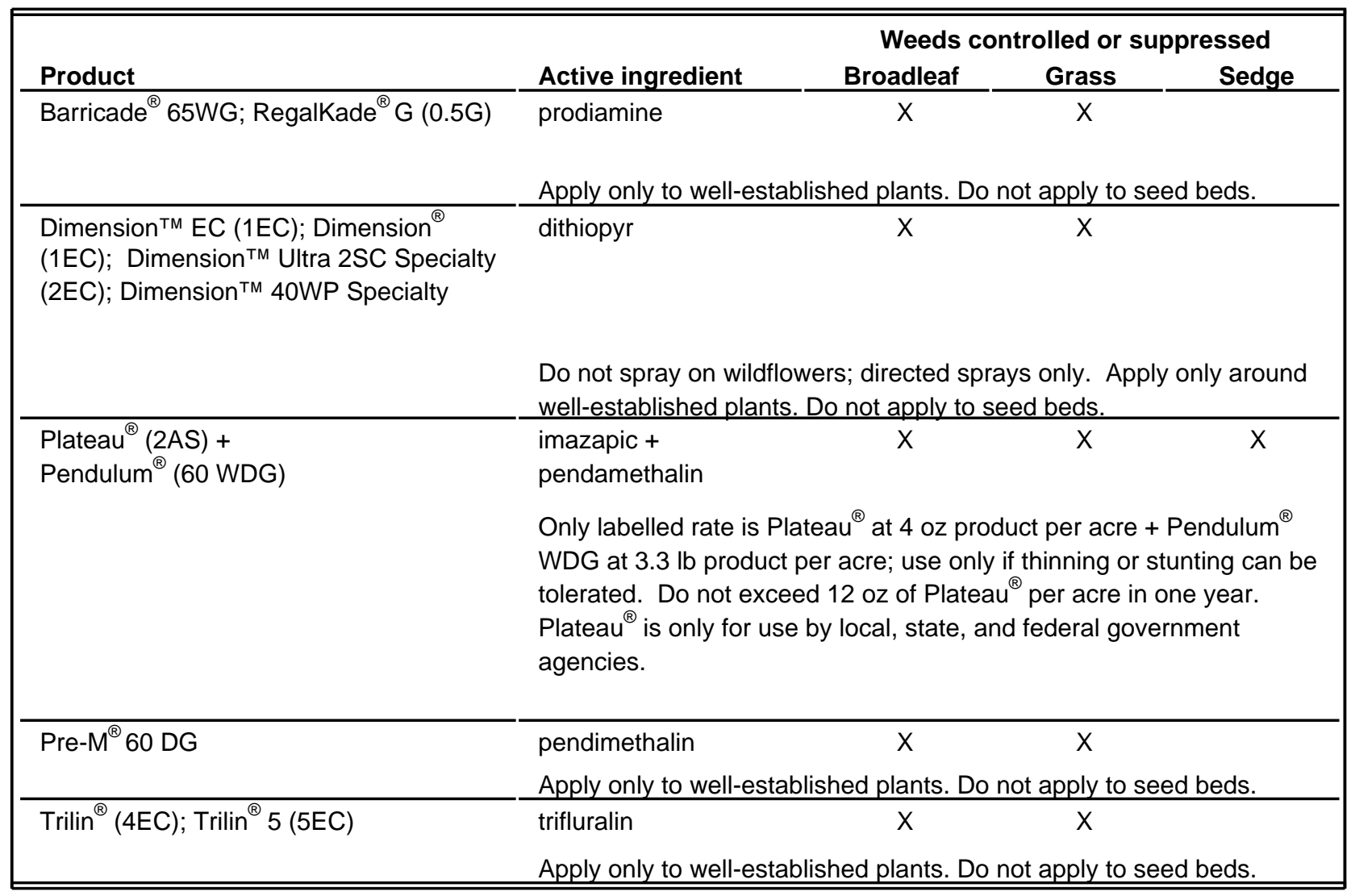

Table 5. Postemergent herbicide products and specific formulations that can be used on wildflower species other than those listed on the label as being tolerant. Details about labelled formulations are in parentheses if all formulation information is not part of the product name.

\begin{tabular}{|c|c|c|c|}
\hline \multirow[b]{2}{*}{ Product } & \multirow[b]{2}{*}{ Active ingredient } & \multicolumn{2}{|c|}{ Weeds controlled or suppressed } \\
\hline & & Grass & Sedge \\
\hline \multirow[t]{2}{*}{ Fusilade $^{\circledR}$ II (2EC); Ornamec ${ }^{\circledR}(0.5 E C)$} & fluazifop & $x$ & \\
\hline & No common wildflowers listed on label & ing toler & \\
\hline \multirow[t]{2}{*}{ Plateau $^{\circledR}(2 A S)$} & imazapic & $x$ & $\mathrm{x}$ \\
\hline & \multicolumn{3}{|c|}{$\begin{array}{l}\text { May cause some injury to wildflowers and/or delay flowering when applied } \\
\text { after emergence of wildflowers. Do not exceed } 12 \text { oz of product per acre in } \\
\text { one year. Only for use by local, state, and federal government agencies. }\end{array}$} \\
\hline \multirow[t]{2}{*}{$\operatorname{Vantage}^{\circledR}(1 \mathrm{EC})$} & sethoxydim & $x$ & \\
\hline & \multicolumn{3}{|c|}{$\begin{array}{l}\text { Apply prior to blooming. May cause temporary leaf speckling; new growth is } \\
\text { normal. }\end{array}$} \\
\hline
\end{tabular}


Table 6. Postemergent herbicide products and specific formulations labelled for use only on specific genera or species of wildflowers. Details about labelled formulations are in parentheses if all formulation information is not part of the product name. Check the label for the list of wildflower genera or species on which these products can be used.

\begin{tabular}{|c|c|c|c|c|}
\hline \multirow[b]{2}{*}{ Product } & \multirow[b]{2}{*}{ Active ingredient } & \multicolumn{3}{|c|}{ Weeds controlled or suppressed } \\
\hline & & Broadleaf & Grass & Sedge \\
\hline \multirow[t]{2}{*}{ Acclaim $^{\circledR}$ Extra $(0.57 \mathrm{EC})$} & fenoxaprop & & $\bar{x}$ & \\
\hline & \multicolumn{4}{|c|}{ May cause temporary injury to succulent, rapidly growing wildflowers. } \\
\hline \multirow[t]{2}{*}{ Envoy $^{\circledR}(0.94 \mathrm{EC})$} & clethodim & & $\mathrm{x}$ & \\
\hline & \multicolumn{4}{|c|}{$\begin{array}{l}\text { May cause minor leaf spotting on treated foliage; new growth is not } \\
\text { affected. }\end{array}$} \\
\hline
\end{tabular}

